\title{
Harvestmen (Opiliones) of the Sikhote-Alin and the Far Eastern Marine Biosphere Reserves, Russia
}

\section{Сенокосщы (Opiliones) Сихотэ-Алинского и Аальневосточного морского биосферного заповедников}

\author{
E.V. Prokopenko*, M.E. Sergeev** \\ E.B. Прокопенко*, М.Е. Сергеев**
}

\begin{abstract}
* GOU VPO Donetsk National University, Schorsa Str. 46, Donetsk 83054 Ukraine. E-mail: helen_procop@mail.ru
* ГОУ ВПО Донецкий национальный университет, ул. Щорса 46, Донецк 83054 Украина.

** Федеральный научный центр биоразнообразия наземной биоты Восточной Азии ДВО РАН, пр. 100-летия Владивостока 159, Владивосток 690022 Россия. E-mail: eksgauster@inbox.ru.

** Federal Research Center for Terrestrial Biota Biodiversity in East Asia FEB RAS, Prosp. 100-letiya Vladivostoka 159, Vladivostok 690022 Russia.
\end{abstract}

Key words: Opiliones, Far East, protected areas, Primorskii Krai, faunistics.

Ключевые слова: Opiliones, Дальний Восток, охраняемые природные объекты, Приморский край, фаунистика.

Abstract. An annotated list of 8 Opiliones species within 3 families, Caddidae (1 sp.), Sclerosomatidae (3 spp.) and Phalangiidae (4 spp.), recorded from the Sikhote-Alin Nature Reserve, the Far East Marine Reserve and Russky Island of the Russian Far East is presented. 7 Opiliones species are recorded for the Sikhote-Alin Nature Reserve, 5 species for the Far Eastern Marine Reserve, and one species, Oligolophus tienmushanensis Wang, 1941 (Phalangiidae), is recorded for Russky Island. All species are distributed in the Far East, except Caddo agilis Banks, 1892, also known from NorthEast America and Japan. A rare and locally distributed species, Homolophus albofasciatus (Kulczyński, 1901), is briefly described and illustrated.

Резюме. В Сихотэ-Алинском государственном природном биосферном заповеднике, Дальневосточном морском биосферном заповеднике и на о. Русский отмечено 8 видов сенокосцев, принадлежащих к 3 семействам: Caddidae (1 вид), Sclerosomatidae (3 вида) and Phalangiidae (4 вида). Наибольшим видовым богатством опилиофауны характеризуется Сихотэ-Алинский заповедник, на его территории обнаружено 7 видов. В Дальневосточном морском заповеднике собрано 5 видов, на о. Русский - 1 вид, Oligolophus tienmushanensis Wang, 1941 (Phalangiidae). Распространение всех отмеченных видов ограничено Дальним Востоком, за исключением Caddo agilis Banks, 1892, который также отмечен на востоке Северной Америки и в Японии. В статье приведён аннотированный список видов сенокосцев и дано краткое описание морфологических особенностей редкого и локально распространённого вида Homolophus albofasciatus (Kulczyński, 1901).

\section{Introduction}

Harvestmen (Opiliones) is a group of arachnids widespread in a wide range of different geographical zones and biotopes. Currently 8707 species of Opilionidae have been described [Kury et al., 2020], but the species diversity of this group is estimated at about 10000 species [Pinto-Da-Rocha et al., 2007].

The first information on harvestmen of Primorsky Krai appeared in the work by V.V. Redikortsev [1936] with a description of Metagagrella ussuriensis Redikortsev, 1936 (now a junior synonym of Melanopa grandis Roewer, 1910). Almost thirty years later, redescription of Mitopus mongolicus Roewer, 1912 and Homolophus arcticus Banks, 1893 (as Euphalangium albofasciatus (Kulczyński, 1901)) from the «Ussuriysky Krai»» was published in a paper by W. Staręga [1964]. Later, S.I. Ljovuschkin [1972] described Taracus birsteini (Lyovushkin, 1972) from the Belii Dvorets Cave (Partizansky Raion). In the «Katalog der Weberknechte (Opiliones) der Sowjet-Union» by W. Staręga [1978] only four species were registered from Primorsky Krai: T. birsteini, M. grandis, M. m. mongolicus, and $H$. arcticus (as Egaenus zichyi Kulczyński, 1901). A year later, I.I. Gritsenko [1979a, b] listed seven species for this territory: Hamitergum eobium (Redikortsev, 1936) (as Lophacantus eus), M. grandis (as M. damila and M. ussuriensis), M. m. mongolicus, H. arcticus (as E. albofasciatum), Oligolophus tienmushanensis Wang, 1941, Phalangium opilio Linnaeus, 1761, and Bidentolophus bidens (Simon, 1880) (as E. transbaicalicum). In addition, Sabacon makinoi Suzuki, 1949 [Gritsenko, 1979a] as $S$. habei Suzuki, 1966 was described exclusively based on juvenile specimens from the Kedrovaya Pad Nature Reserve. This finding still requires confirmation [Trilikauskas, 2015].

More recent data on harvestmen of Primorsky Krai are available from the works of A.N. Chemeris [Chemeris et al., 1998; Chemeris, 2000], where several species 
are redescribed and Mitopus morio (Fabricius, 1779) and Psathyropus tenuipes Koch, 1878 are added to the regional check-list. The record of Nipponopsalis coreana Suzuki, 1966 in Primorsky Krai (high number of specimens was collected in the vicinity of Vladivostok) is erroneous and should be referred to T. birsteini [Schönhofer, 2013].

Another species described from Primorsky Krai was Sabacon rossopacificus Martens, 2015 from Velikan Cave (Partizansky Raion) [Martens, 2015]. Caddo agilis Banks, 1892 was recorded in the Sikhote-Alin Nature Reserve in 2020 [Prokopenko, Sergeev, 2020]. This is the first species of the family Caddidae registered from continental part of the Russian Far East. To date, fourteen species of harvestmen from five families are registered for Primorsky Krai (Table 1).

Although the opilionid fauna of Primorsky Krai is relatively well known, data concerning the Sikhote-Alin State Nature Biosphere Reserve and the Far Eastern Marine Biosphere Reserve are still missed. Thus, the present paper increases knowledge on the opilionid fauna of these protected areas.

\section{Material and methods}

This paper is based on study of the 55 mature and the 14 juvenile harvestmen specimens, collected by the second author during 2015-2020 field seasons in the localities listed in Table 2. The material was collected mainly by hands and by the pitfall traps.

All measurements are in mm. Photographs were taken by USB Digital camera Lens Mount attached to a
Zeiss Primo Star microscope and a MBS-10 stereomicroscope. All material is deposited in the personal collection of the first author.

Sikhote-Alin State Nature Biosphere Reserve was founded in 1935 and is the largest protected nature reserve in the coniferous-broadleaved forest belt of Eurasia and America. At present it is over 400000 ha and extends inland from the coast of the Japan Sea, including the western and eastern spurs of the Sikhote-Alin mountain range. Mountain slopes of different steepness occupy up to $80 \%$ of the reserve's area [Utenkova, Labetskaya, 2006; Gromyko, 2010]. Flora of Sikhote-Alin Nature Reserve includes 1094 species of vascular plants from 504 genera and 135 families [Pimenova, 2016]. Significant altitudinal gradient determines seven altitudinal zones of vegetation, coastal vegetation, belt of coastal oak forests, belt of pine-broadleaved forests, fir-spruce forests, stone-birch forests, belt of cedar shrub, and mountain-tundra vegetation. Forests of other formations amount about $25 \%$ of the total area of the forest cover. Herbal vegetation occupies only about $2 \%$ [Pimenova, 2016]. At present, fires are one of the most important factors causing the transformation of the vegetation cover of the reserve [Gromyko, 2010].

Far Eastern Marine Biosphere Reserve was founded in 1978, and includes a group of islands in the Peter the Great Bay and sections of the mainland shoreline. The reserve's territory is about 64000 ha, about $98 \%$ of which belongs to the bay water area. Vegetation cover of the islands differs significantly from that of the mainland, due to climatic conditions occur. The islands are strongly influenced by winter winds, and therefore

Table 1. Taxonomic composition of harvestmen of Primorsky Krai and the number of specimens collected in the Sikhote-Alin Reserve, Far Eastern Marine Reserve and Russky Island

Таблица 1. Таксономический состав сенокосщев Приморского края и число экземпляров, собранных в СихотэАлинском и Аальневосточном морском заповедниках, а также на острове Русский

\begin{tabular}{|c|c|c|c|c|}
\hline \multirow{2}{*}{ Family } & \multirow{2}{*}{ Species } & \multicolumn{3}{|c|}{ Number of collected specimens } \\
\hline & & S.-A. Res. & F.-E. Res. & Russky Island \\
\hline \multirow{2}{*}{ Sabaconidae } & Sabacon makinoi Suzuki, 1949 & - & - & - \\
\hline & Sabacon rossopacificus Martens, 2015 & - & - & - \\
\hline Taracidae & Taracus birsteini Lyovushkin, 1972 & - & - & - \\
\hline Caddidae & Caddo agilis Banks, 1892 & 16 & - & - \\
\hline \multirow{3}{*}{ Sclerosomatidae } & Hamitergum eobium (Redikortsev, 1936) & 3 & 2 & - \\
\hline & Melanopa grandis Roewer, 1910 & 3 & 1 & - \\
\hline & Psathyropus tenuipes Koch, 1878 & - & 1 & - \\
\hline \multirow{7}{*}{ Phalangiidae } & Bidentolophus bidens (Simon, 1880) & - & - & - \\
\hline & Homolophus albofasciatus (Kulczyński, 1901) & 5 & - & - \\
\hline & Homolophus arcticus Banks, 1893 & 8 & 1 & - \\
\hline & Mitopus mongolicus mongolicus Roewer, 1912 & 6 & - & - \\
\hline & Mitopus morio (Fabricius, 1779) & - & - & - \\
\hline & Oligolophus tienmushanensis Wang, 1941 & 5 & 3 & 1 \\
\hline & Phalangium opilio Linnaeus, 1758 & - & - & - \\
\hline
\end{tabular}


Table 2. Collecting localities and number of specimens collected

Таблица 2. Места сбора сенокосцев и количество собранных экземпляров

\begin{tabular}{|c|c|c|c|}
\hline № & Localities & Coordinates & $\begin{array}{l}\text { Number of collectec } \\
\text { specimens }\end{array}$ \\
\hline \multicolumn{4}{|c|}{ Sikhote-Alin Nature Reserve: } \\
\hline 1 & natural landmark «Abrek», Skrytaya River Valley & $45,0982^{\circ} \mathrm{N}, 136,6908^{\circ} \mathrm{E}$ & 11 \\
\hline 2 & Terney Village vicinity & $45,0256^{\circ} \mathrm{N}, 136,3714^{\circ} \mathrm{E}$ & 4 \\
\hline 3 & natural landmark «Blagodatnoe», Cape North vicinity & $44,5712^{\circ} \mathrm{N}, 136,3248^{\circ} \mathrm{E}$ & 1 \\
\hline 4 & $\begin{array}{l}\text { natural landmark «Blagodatnoye», upper reaches of Sukhoy } \\
\text { Spring }\end{array}$ & $44,5857^{\circ} \mathrm{N}, 136,3109^{\circ} \mathrm{E}$ & 10 \\
\hline 5 & natural landmark «Blagodatnoye», near Blagodatnoye Lake & $44,5714^{\circ} \mathrm{N}, 136,3250^{\circ} \mathrm{E}$ & 4 \\
\hline 6 & natural landmark «Golubichnoye», near Golubichnoye Lake & $44,5430^{\circ} \mathrm{N}, 136,3136^{\circ} \mathrm{E}$ & 6 \\
\hline 7 & natural landmark «Kunaleika», cordon «Khanov» & $44,8966^{\circ} \mathrm{N}, 136,3371^{\circ} \mathrm{E}$ & 2 \\
\hline 8 & natural landmark «Ust-Serebryannyi», Serebryanka River Valley & $45,0825^{\circ} \mathrm{N}, 136,2243^{\circ} \mathrm{E}$ & 4 \\
\hline 9 & natural landmark «Yasnaya», Zabolochennaya River Valley & $44,5325^{\circ} \mathrm{N}, 136,2018^{\circ} \mathrm{E}$ & 4 \\
\hline 10 & natural landmark «Yasnaya», Yasnaya River Valley & $45,2370^{\circ} \mathrm{N}, 136,5074^{\circ} \mathrm{E}$ & 1 \\
\hline 11 & $\begin{array}{l}\text { natural landmark «Ust-Prokhodnaya», saltmarsh } \\
\text { «Kaplanovsky», upper reaches of Kolumba River }\end{array}$ & $45,3324^{\circ} \mathrm{N}, 136,1365^{\circ} \mathrm{E}$ & 3 \\
\hline 12 & $\begin{array}{l}\text { natural landmark «Snezhnaya», upper reaches of Serokamenka } \\
\text { River }\end{array}$ & $45,6647^{\circ} \mathrm{N}, 136,1101^{\circ} \mathrm{E}$ & 4 \\
\hline 13 & $\begin{array}{l}\text { natural landmark «Svetlaya», Serokamenka River Valley (at the } \\
\text { confluence with Columbe River). }\end{array}$ & $45,5389^{\circ} \mathrm{N}, 135,9850^{\circ} \mathrm{E}$ & 2 \\
\hline 14 & $\begin{array}{l}\text { natural landmark «Sporny», headwaters of Serebryanka River } \\
\text { (Sporny Spring Valley) }\end{array}$ & $45,1940^{\circ} \mathrm{N}, 135,9901 \mathrm{E}$ & 4 \\
\hline 15 & Russkiy Island, $0.5 \mathrm{~km} \mathrm{~S}$ of Vladivostok, Ajax Bay & $43,0000^{\circ} \mathrm{N}, 131,5000^{\circ} \mathrm{E}$ & 1 \\
\hline \multicolumn{4}{|c|}{ Far East Marine Reserve: } \\
\hline 16 & Popova Island, $20 \mathrm{~km}$ SW of Vladivostok, Pogranichnaya Bay & $42,9543^{\circ} \mathrm{N}, 131,7383^{\circ} \mathrm{E}$ & 4 \\
\hline 17 & Furugelma Island & $42,2800^{\circ} \mathrm{N}, 130,5520^{\circ} \mathrm{E}$ & 4 \\
\hline \multicolumn{3}{|l|}{ Total } & 69 \\
\hline
\end{tabular}

creeping forms of tree and shrub vegetation are widespread. In addition, unlike the mainland forests, which suffer from fires and logging, the human impact on plant communities in the islands is less pronounced and the advanced stages of demutation are much greater. The islands of the Peter the Great Bay are relatively small. They located on the continental shelf near the coast. These islands are spurs of the coastal mountain rises, which were part of the continent in the Pleistocene, from which they separated between 11000 and 8500 years ago. Thus, there is an opportunity to study the composition and structure of peculiar communities of terrestrial animals and ways of their adaptation to the island habitats in a natural experiment [Velizhanin, 1976; Belyaev, 2013; Legalov, Sergeev, 2018; Sergeev, 2019].

\section{Results and discussion}

In toto, eight harvestmen species from five families, Caddidae (1 species), Sclerosomatidae (3 species) and Phalangiidae (4 species) were recorded. Opiliofauna of the Sikhote-Alin Nature Reserve is the most speciesrich and includes seven species (Table 1). Five opilionid species were found in the Far Eastern Marine Reserve. Only one species, Oligolophus tienmushanensis (family Phalangiidae), was registered on Russkii Island.
All species are distributed in the Far East, except Caddo agilis Banks, 1892, also known from North-East America and Japan.

The annotated check-list of harvestmen of the Sikhote-Alin Reserve and the Far Eastern Marine Reserve is presented below, and brief morphological description of the rare local species $H$. albofasciatus is given.

Caddidae Banks, 1893

Caddo agilis Banks, 1892

Caddo agilis Banks, 1892: Primorskii Krai: Sikhote-Alin Reserve [Prokopenko, Sergeev, 2020].

Material. Sikbote-Alin Reserve: natural landmark «Abrek», Skrytaya River Valley, 3-5.VII.2020, 11우; natural landmark «Blagodatnoe», upper reaches of Sukhoi Spring, slopes of Lysaya Mount, 9-10.VII.2020, 5우.

Distribution. USA, Canada, Japan, Russian Federation: Primorsky Krai, Kuril Islands, Sakhalin Island [Suzuki, 1958; Schear, 1975; Cokendolpher, Lee, 1993; Giribet, Kury, 2007; Shultz, Regier, 2009; Groh, Giribet, 2015; Shultz, 2018; Prokopenko, Sergeev, 2020].

Sclerosomatidae Simon, 1879 Hamitergum eobium (Redikorzev, 1936)

Lophacantus eobius Redikorzev, 1936: Gritsenko, 1979b Primorsky Krai: Vladivostok, Kedrovaya Pad Biosphere Reserve, Tigrovoi Village (Partizanskii Raion); 
Hamitergum eobium (Redikorzev, 1936: Chemeris et al., 1998) - Kedrovaya Pad Biosphere Reserve, Ussuriyskiy Nature Reserve; Chemeris, 2000 - near Anisimovka Village, Kangauz River (Shkotovskii Raion), Chuguev Field Station (Chuguevskii Raion).

Material. Sikbote-Alin Reserve: natural landmark «Kunaleika», cordon «Khanov», 21.VI.2018, 19; natural landmark «Blagodatnoe», Cape North vicinity, 2.VIII.2018, 1 , ibidem, upper reaches of Sukhoy Spring, slopes of Lysaya Mount, 10.VII.2020, 1․ Far Eastern Marine Reserve: Popov Island, 3-4.V.2019, 2 29.

Distribution. North Korea, Russian Federation: Chita Region, Far East [Chemeris et al., 1998].

\section{Melanopa grandis Roewer, 1910}

Metagagrella ussuriensis Redikorzew, 1936: Redikortsev, 1936, Roewer, 1954, Starkga, 1978, Gritsenko, 1979b Primorskii Krai: Partizansk («the valley of the Suchan River»), Kedrovaya Pad Biosphere Reserve, Vinogradovka Village (Anuchinskii Raion), Chuguevka Village (Chuguevskii Raion), Reshetnikovo Village (Pogranichnyi Raion);

Metagagrella damila Šilhavý, 1976: Gritsenko, 1979b Kedrovaya Pad Biosphere Reserve, Ussuriyskiy Nature Reserve;

Melanopa grandis Roewer, 1910: Chemeris, 2000 Lazovsky Nature Reserve, Andreevka Village and Bryusa Peninsula, Kruglaya Bay (Khasanskii Raion), Anisimovka Village, Kangauz River (Shkotovskii Raion), Ussuriyskiy Nature Reserve, Kedrovaya Pad Biosphere Reserve, vicinity of Vladivostok, Peter the Great Bay.

Material. Sikbote-Alin Reserve: natural landmark «Snezhnaya», upper reaches of Serokamenka River, 11.VIII.2017, 19; natural landmark «Sporny», headwaters of Serebryanka River, 29.VII.2020, $20^{7} \sigma^{7}$. Far Eastern Marine Reserve: Popova Island, 26.VIII.2018, 1ㅇ.

Distribution. Japan, Korea, China, Russian Federation: Primorsky Krai [Chemeris, 2000; Zhang, Zhang, 2013].

\section{Psathyropus tenuipes Koch, 1878}

Psathyropus tenuipes Koch, 1878: Chemeris, $2000-$ Andreevka Village (Khasanskii Raion), vicinity of Vladivostok, Peter the Great Bay.

Material. Far Eastern Marine Reserve: Furugelma Island, 18-20.VIII.2018, 1ㅇ.

Distribution. Russia: south Kuril Islands, Sakhalin, Moneron [Crawford, Marusik, 2007], Primorskii krai [Chemeris, 2000]; Japan: Honshu, Hokkaido [Suzuki, Tsurusaki, 1983].

Phalangiidae Simon, 1879

Homolophus albofasciatus (Kulczyński, 1901) Fig. 1.

Euphalangium albofasciatum Kulczyński, 1901: Staręga, 1964, Gritsenko, 1979a, b: Primorsky Krai: «Ussuriyskiy Krai», «Primorye», Ussuriisk, Anisimovka Village (Shkotovskii Raion), Novokachalinsk Village (Khankaiskii Raion).

Material. Sikbote-Alin Reserve: natural landmark «Golubichnoye», near Golubichnoye Lake, 20.VIII.2015, $3 \sigma^{7} \sigma^{7}$ ibidem, 18.IX.2018, 1ㅇ, $10^{7}$.

Distribution. North Korea, Mongolia, China, Russian Federation: Siberia, Primorsky Krai [Staręga, 1964; Cokendolpher, 1987; Snegovaya, Cokendolpher, 2021].

Description. Deatil characteristics see Snegovaya, Cokendolpher [2021]. Measurements. Male. Body length - 6.1, body width -3.9 , cephalothorax length -2.0 , ocularium width - 0.7, «clypeus» (space between ocularium and front margin of carapace) - 1.0; chelicera: basal segment - 1.6, distal segment - 1.8, forceps length -1.0 . Penis: length 3.2 , width at base -0.6 , width in the narrowest part -0.15 .

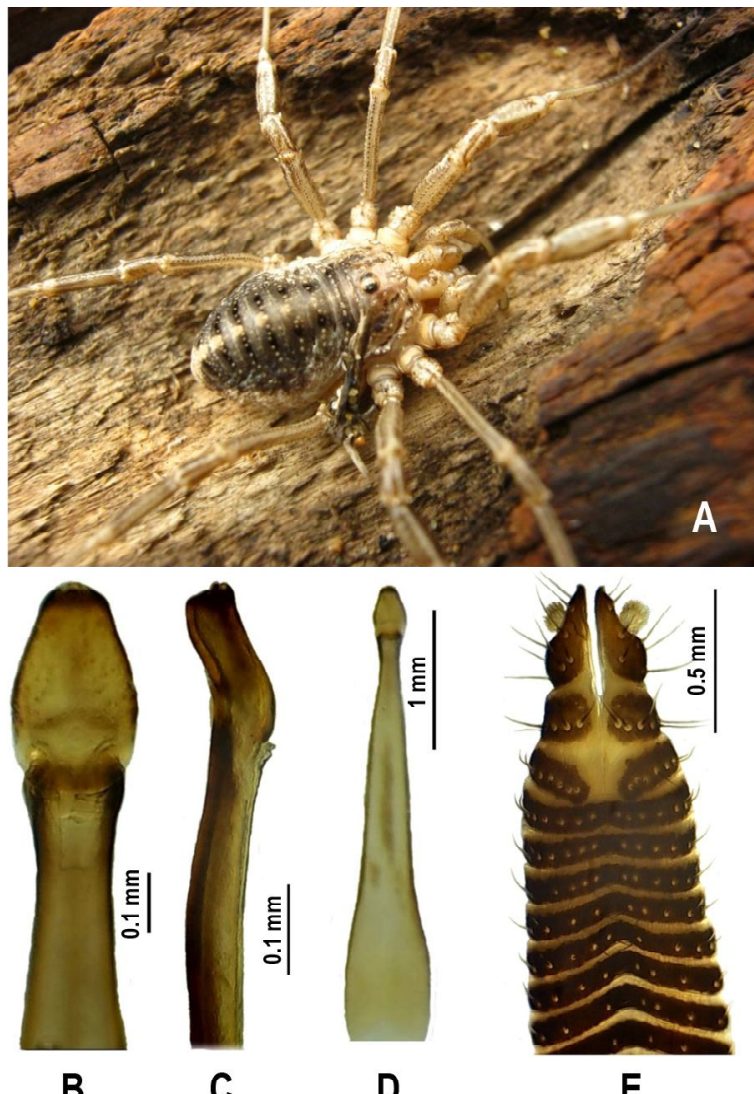

B
D
E

Fig. 1. Details of Homolophus albofasciatus, photo by M.E. Sergeev. A - external appearance of male from vicinity of Golubichnoe Lake; B, D - glans dorsally (glans are up, stylus is broken), C - glans laterally, D - penis dorsally, E ovipositor dorsally.

Рис. 1. Аетали строения Homolopbus albofasciatus, фотографии М.Е. Сергеева. А - внешний виА самца из окр. озера Голубичного; В, D - головка дорсально (головка наверху, стилюс повреждён), С - головка катерально, D пенис дорсально, Е - яйцеклад дорсально.

Length of palp and legs are given in Table 3. Male in nature is in fig. 1, A, penis is in fig. 1, B-D. Female. Measurements. Body length -8.5 , body width -5.0 , thorax length -1.6 , ocularium width -0.5 , «clypeus» -0.8 ; chelicerae: basal segment - 1.0, distal segment - 1.3, forceps length - 0.7 . Length of palp and legs are given in Table 4. Ovipositor as fig. 1 (E).

\section{Homolophus arcticus Banks, 1893}

Euphalangium albofasciatum (Kulczyński, 1901): «Ussuriyskiy Krai»;

Egaenus zichyi Kulczyński, in Zichy 1901: Staręga, 1978; Tsurusaki, 1987 - Primorsky Krai;

Homolophus arcticus Banks, 1893: Chemeris, 2000 Primorsky Krai: Ussuriyskiy Nature Reserve, Chuguevskaya Field Station (Chuguevskii Raion), Anisimovka Village, Kangauz River (Shkotovskii Raion).

Material. Sikbote-Alin Reserve: Terney village vicinity, «sopka» (hill), broad-leaved forest, 30.VII.2018, 20+; ibidem, 9.VIII.2018, 1\%; natural landmark «Ust-Prokhodnaya», 
Table 3. Length of male palpi and legs of Homolophus albofasciatus, $\mathrm{mm}$

Таблица 3. Алина ног и пальп самџа Homolopbus albofasciatus в мм

\begin{tabular}{|c|c|c|c|c|c|c|}
\hline Palp and legs segments & Femur & Patella & Tibia & Metatarsus & Tarsus & Total \\
\hline Palp & 1.6 & 0.8 & 1.1 & - & 2.0 & 5.5 \\
\hline Leg I & 2.9 & 1.4 & 2.2 & 3.0 & 5.1 & 14.6 \\
\hline Leg II & 4.2 & 1.5 & 3.7 & 3.7 & 10.2 & 23.3 \\
\hline Leg III & 2.8 & 1.4 & 2.9 & 3.5 & 5.6 & 16.2 \\
\hline Leg IV & 4.0 & 1.4 & 3.2 & 5.0 & 7.7 & 21.3 \\
\hline
\end{tabular}

saltmarsh «Kaplanovsky», upper reaches of Kolumba River, pine-broadleaved forest, 21.VIII.2017, 19; natural landmark «Svetlaya», Serokamenka River Valley (at the confluence with Columbe River), 12.X.2017, 2o+9; natural landmark «Yasnaya», Zabolochennaya River Valley, 8-12.VII.2018, 1; natural landmark «Golubichnoye», near Golubichnoye Lake, 18.IX.2018, 1․ Far Eastern Marine Reserve: Furugelma Island, 1820.VIII.2018, 1 ㅇ․

Distribution. China (Gansu, Xinjiang, Sichuan), Japan (Hokkaido), Korea, Mongolia, Tibet, Russian Federation: Chitinskaya Oblast, Yakutia, Commandor Islands, Magadanskaya Oblast, Sakhalin Island, Kamchatka, Khabarovskii Krai, Primorskii Krai [Chemeris, 2000; Staręga, 2003; Snegovaya, Cokendolpher, 2021].

\section{Mitopus mongolicus mongolicus Roewer, 1912}

Mitopus mongolicus mongolicus Roewer, 1912: Staręga, 1964, 1978; Gritsenko, 1979b; Chemeris, 2000 - Primorsky Krai: Ussuriyskiy Nature Reserve, Kedrovaya Pad Biosphere Reserve, Reshetnikovo Village (Pogranichnyi Raion), Anisimovka Village (Shkotovskii Raion), «Ussuriyskiy Krai».

Material. Sikbote-Alin Reserve: natural landmark «Snezhnaya», upper reaches of Serokamenka River, 11.VIII.2017, 19; natural landmark «Yasnaya», Zabolochennaya River Valley, 8-12.VII.2018, 10'; natural landmark «Blagodatnoye», near Blagodatnoye Lake, 27.IX.2018, 390; natural landmark «Sporny», headwaters of Serebryanka River (Sporny Spring Valley), 29.VII.2020, 1 ㅇ.

Distribution. Mongolia, Russian Federation: Kamchatka, Primorsky Krai [Chemeris, 2000].

\section{Oligolophus tienmushanensis Wang, 1941}

Oligolophus tienmushanensis Wang, 1941: Gritsenko, 1979b, Chemeris, 2000 - Primorsky Krai: Kedrovaya Pad Biosphere Reserve, vicinities of Vladivostok and Ussuriisk, Peter the Great Bay, Andreevka Village (Khasanskii Raion).

Material. Sikbote-Alin Reserve: Terney Village vicinity, «sopka» (hill), broad-leaved forest, 9.VIII.2018, 19; natural landmark «Ust-Prokhodnaya», saltmarsh «Kaplanovsky», upper reaches of Kolumba River, pine-broad-leaved forest,
21.VIII.2017, 1ㅇ, 10 ; natural landmark «Blagodatnoe», Cape North vicinity, 2.VIII.2018, 19웅 ibidem, near Blagodatnoye Lake, 27.IX.2018, 107. Far Eastern Marine Reserve: Island Furugelma, 17.VIII.2018, 2009; Popova Island, 26.VIII.2018, 1우. Russky Island: 31.VIII.2018, 1 우.

Distribution. North Korea, Russian Federation: Khabarovskii and Primorskii Krai [Chemeris, 2000].

\section{Acknowledgments}

The authors are grateful for A.N. Chemeris (Tomsk State University) for the help with identification of harvestmen species.

\section{References}

Belyaev E.A. 2013. Features of the fauna of moths (Lepidoptera: Geometridae) of the islands of the Peter the Great Bay // A.I. Kurentsov's Annual Memorial Meetengs. No.24. P.71100. [In Russian].

Chemeris A.N. 2000. Contribution to the knowledge of the harvestman fauna in the Russian Far East and Eastern Siberia (Arachnida: Opiliones) // Arthropoda Selecta. Vol.9. No.1. P. 31-49.

Chemeris A.N., Logunov D.V., Tsurusaki N. 1998. A contribution to the knowledge of the harvestman fauna of Siberia (Arachnida: Opiliones) // Arthropoda Selecta. Vol.7. No.3. P.189-199.

Cokendolpher J.C. 1987. On the identity of the genus Homolophus: a senior synonym of Euphalangium (Opiliones: Phalangiidae) // Acta Arachnologica. No.35. P.89-96.

Cokendolpher J.C., Lee V.F. 1993. Catalogue of the Cyphopalpatores and bibliography of the harvestmen (Arachnida, Opiliones) of Greenland, Canada, U.S.A., and Mexico. Privately Published. Lubbock, Texas: Vintage Press. iii $+82 \mathrm{p}$.

Crawford R.L., Marusik Y.M. 2007. Harvestmen (Arachnida: Phalangida or Opiliones) of Moneron Island // Bogatov V.V., Barkalov V.Yu., Lelei A.S., Makarchenko E.A.,

Table 4. Length of female palpi and legs of Homolophus albofasciatus, mm

Таблиџа 4. Алина ног и пальп самки Homolopbus albofasciatus в мм

\begin{tabular}{|c|c|c|c|c|c|c|}
\hline Palp and legs segments & Femur & Patella & Tibia & Metatarsus & Tarsus & Total \\
\hline Palp & 1.1 & 0.8 & 0.8 & - & 1.5 & 4.2 \\
\hline Leg I & 2.5 & 1.1 & 2.1 & 2.3 & 4.7 & 12.7 \\
\hline Leg II & 4.0 & 1.4 & 3.1 & 3.0 & 9.6 & 21.1 \\
\hline Leg III & 2.4 & 1.1 & 2.2 & 2.6 & 5.0 & 13.3 \\
\hline Leg IV & 3.1 & 1.3 & 3.6 & 4.3 & 7.6 & 19.9 \\
\hline
\end{tabular}


Storozhenko S.Yu. (Eds): Flora and fauna of Moneron Island (Materials of International Sakhalin Island Project). Vladivostok: Dalnauka. P.196-201.

Giribet G., Kury A.B. 2007. Chapter 3. Phylogeny and biogeography // Pinto-da-Rocha, R., Machado, G., Giribet, G. (Eds.): Harvestmen: the biology of the opiliones. Cambridge and London: Harvard University Press. P.62-87.

Gritsenko N.I. 1979a. Harvestman (Opiliones) from the Asian part of the USSR // Proceedings of the Zoological Institute of the Academy of Sciences of the SSSR. No.85. P.28-38. [In Russian].

Gritsenko N.I. 1979b. Materials for the harvestmen fauna (Opiliones) of the Primorsky Kray // Terrestrial arthropods of the Far East. Vladivostok. P.124-132. [In Russian].

Groh S., Giribet G. 2015. Polyphyly of Caddoidea, reinstatement of the family Acropsopilionidae in Dyspnoi, and a revised classification system of Palpatores (Arachnida, Opiliones) // Cladistics. No.31. P.277-290. DOI: https://doi.org/10.1111/ cla. 12087.

Gromyko M.N. 2010. Forest fire characteristic of ecosystems Fires and their impact on the natural ecosystems of Central Sikhote-Alin. Vladivostok: Dalnauka. P.86-103. [In Russian].

Kury A.B., Mendes A.C., Cardoso L., Kury M.S., Granado A. de A. 2020. WCO-Lite: online world catalogue of harvestmen (Arachnida, Opiliones). Version 1.0 - Checklist of all valid nomina in Opiliones with authors and dates of publication up to 2018. Rio de Janeiro. 237 p.

Legalov A.A., Sergeev M.E. 2018. First record of Cionus latefasciatus Voss, 1956 (Insecta: Coleoptera: Curculionidae) in the Russian fauna // Ukrainian Journal of Ecology. Vol.8. No.4. P.514-516.

Ljovuschkin S.I. 1972. Biospeleologica Sovietica XLIII. Report on the first finding of the American genus Taracus Simon, 1879 (Opiliones, Ischyropsalididae) in Asia with a description of $T$. birsteini sp.n. from a cave of the southern part of the Primorsky Krai // Biospeologica Sovetica XLIII. Bulletin of the Moscow Society of Nature Testers. Biological Department. Vol.76. No.3. P.127-133. [In Russian].

Martens J. 2015. Sabacon Simon, 1879 in the Palaearctic: A survey of new and known species from France, Nepal, India, China, Russia and Japan (Arachnida: Opiliones: Sabaconidae) // Biodiversity and Natural Heritage of the Himalaya V. Erfurt: Naturkundemuseum. P.167-210.

Pimenova E.A. 2016. Vascular plants. Plants, mushrooms and lichens of the Sikhote-Alin reserve. Vladivostok: Dalnauka. P.172-365. [In Russian].

Pinto-da-Rocha R., Machado G., Giribet G. 2007. Harvestmen: The Biology of the Opiliones. Harvard University Press: Cambridge MA. 597 p.

Prokopenko E.V., Sergeev M.E. 2020. Note on the northwestern boundary of the family Caddidae (Opiliones) in Asia // Far Eastern Entomologist. No.421. P.10-13. DOI: https:// doi.org/10.25221/fee.421.2.

Redikortsev V.V. 1936. Materials for the Opiliones fauna of USSR // Proceedings of the Zoological Institute of the Academy of Sciences of the SSSR. No.3. P.33-57. [In Russian].

Roewer C.F. 1954. Indoaustralische Gagrellinae (Opiliones, Arachnidae). (Weitere Weberknechte XVIII). 2. Teil //
Senckenbergiana Biologica. Vol.35. Nos 5/6. P.237-292. P1.23-26.

Schear W.A. 1975. The opilionid family Caddidae in North America, with notes on species from other regions (Opiliones, Palpatores, Caddoidea) // The Journal of Arachnology. No.2. P. 65-88.

Schönhofer A.L. 2013. A taxonomic catalogue of the Dyspnoi Hansen and Sørensen, 1904 (Arachnida: Opiliones) // Zootaxa. Vol.3679. No.1. P.1-68. DOI: https://doi.org/10.11646/ zootaxa.3679.1.1

Sergeev M.E. 2019. The leaf beetles (Coleoptera: Chrysomelidae) of the Far Eastern State Marine Reserve, Primorskii Krai // Far Eastern Entomologist. No.375. P.11-19. DOI: 10.25221/ fee. 375.3 .

Shultz J.W. 2018. A guide to the identification of the harvestmen (Arachnida: Opiliones) of Maryland // Northeastern Naturalist. Vol.25. No.1. P.21-49. DOI: https://doi.org/10.1656/ 045.025 .0101 .

Shultz J.W., Regier J.C. 2009. Caddo agilis and C. pepperella (Opiliones, Caddidae) diverged phylogenetically before acquiring their disjunct, sympatric distributions in Japan and North America // The Journal of Arachnology. No.37. P.238-240.

Snegovaya N.Yu., Cokendolpher J.C. 2021. Further studies on harvestmen genus Homolophus (Opiliones: Phalangiidae), with descriptions of two new species // Zootaxa. Vol.4908. No.3. P.301-353. DOI: 10.11646/zootaxa.4908.3.1.

Staręga W. 1964. Materialien zur Kenntnis der ostasiatischen Weberknechte (Opiliones). I-IV // Annales Zoologici (Polska Akademia Nauk). Vol.22. No.17. P.387-410.

Starega W. 1978. Katalog der Weberknechte (Opiliones) der SowjetUnion // Fragmenta Faunistica. Vol.23. No.10. P.197-241.

Staręga W. 2003. On the identity and synonymies of some Asiatic Opilioninae (Opiliones: Phalangidae) // Acta Arachnologica. Vol.52. No.2. P.91-102.

Suzuki S. 1958. Occurrence in Japan of Caddo agilis Banks (Opiliones) // Annotationes Zoologicae Japonenses. Vol.31. No.4. P.225-228.

Suzuki S., Tsurusaki N. 1983. Opilionid fauna of Hokkaido and its adjacent areas // Journal of Science of the Hiroshima University, Zoology. Vol.23. No.2. P.195-243.

Trilikauskas L.A. 2015. Harvestman of the genus Sabacon (Opiliones: Sabaconidae) in specially protected natural areas of Siberia and the Russian Far East // Mountain Ecosystems of Southern Siberia: study, protection and rational nature management. Proceedings of Tigirek Reserve. No.7. P.236238. [In Russian].

Tsurusaki N. 1987. Two species of Homolophus newly found from Hokkaido, Japan (Arachnida: Opiliones: Phalangiidae) // Acta Arachnologica. Vol.35. No.2. P.97-107.

Utenkova A.P., Labetskaya N.I. 2006. Relief. Flora and fauna of the Sikhote-Alin reserve. Vladivostok: Primpoligrafkombinat. P.16-20. [In Russian].

Velizhanin A.G. 1976. Time of isolation of the mainland islands of the North Pacific Ocean // Reports of the USSR Academy of Sciences. Vol.2316. No.1. P.205-207. [In Russian].

Zhang Ch., Zhang F. 2013. Notes on some species of the genus Melanopa (Opiliones: Sclerosomatidae: Gagrellinae) from China, with description of a new species // The Journal of Arachnology. No.41. P.306-318. 